\title{
PRODUCTION PARAMETERS OF LAMBS IN FATTENING DEPENDING ON GENOTYPE $^{1}$
}

\author{
Dragana Ružić-Muslić, M.P.Petrović, S Josipović ${ }^{2}$
}

Contents: Results of the investigation of production performances of lambs in fattening depending on the genotype are presented in this paper. Trial was carried out on 60 suckling lambs divided into two groups. Investigated material belonged to following genotypes:

- $\mathrm{R}_{2}$ (PxW)- Pramenka x Württemberg (two breed crosses)(I)

- $\mathrm{F}_{1}\left(\mathrm{R}_{2}(\mathrm{PxW}) \mathrm{x}\right.$ IdF- Pramenka $\mathrm{x}$ Württemberg x Ile de France (three breed crosses)(II)

Average body mass on lambs at the beginning of trial was approx. $15 \mathrm{~kg}$ and at the end of trial approx. $30 \mathrm{~kg}$. Fattening lasted for 60 days. Nutrition of lambs consisted of mother's milk, concentrate mixture and alfalfa hay (ad libitum). Following production parameters were monitored: body mass, average daily gain, total gain, consumption and conversion of feed and nutritious substances, dressing percentage, meat yield according to categories, chemical-technological and sensor traits of meat of investigated genotypes. Data obtained in research was processed using analysis of variance.

Average daily gain was $239 \mathrm{~g}$ (I) and $285 \mathrm{~g}$ (II). Conversion of hay and concentrate $(\mathrm{g} / \mathrm{kg})$ in different genotypes - I and II was: 1610 and $2090 \mathrm{~g}$ (I) and 1200 and $1770 \mathrm{~g}$ (II), energy (MJ NEM / kg): 22,76 (I) and 18,76 (II), digestible crude protein - DCP (g/kg): 506 (I) and 412g (II).

No significant difference between genotypes was established in regard to dressing percentage, yield of meat according to categories, chemical-technological and sensor traits of lamb meat.

Key words: lambs, genotype, crossing, heterosis, daily gain, feed conversion, dressing percentage

\section{Introduction}

Low production of mutton and lamb meat is consequence of numerous factors such as: poor breed structure, inadequate nutrition and primitive breeding methods.

In order to improve the quantitative and qualitative traits of meat improvement of sheep of low productive population (Pramenka) using rams of meat breeds such as Württemberg and Ile de France is carried out.

Expected results of crossing depend on genetic differences between crossed populations but also from the system of crossing. In the two breed crossing system only heterosis effect of individual animal is used, whereas in three breed crossing mother's heterosis is added to the heterosis of individual animal (Petrović et al., 2000).

Realization of genetic potential for meat production is only possible in conditions of adequate nutrition of heads of livestock (Zeremski, 1989, Negovanović et al., 1983, Soeparno and Davis, 1987).

Objective of our work was to compare production parameters of the two groups of crosses: Pramenka x Württemberg (two breed crosses) and Pramenka x Württemberg x Ile de France (three breed crosses) with same housing and nutrition conditions during our trial.

\section{Material and methods}

Research was carried out on experimental sheep farm of the Institute for Animal Husbandry, Belgrade-Zemun. Trial included 60 suckling lambs of two genotypes, 30 lambs per each genotype:

I $\quad \mathrm{R}_{2}(\mathrm{PxW})$ - Pramenka $\mathrm{x}$ Württemberg (two breed crosses)

II $\quad F_{1}\left(\mathrm{R}_{2}(\mathrm{PxW}) \times\right.$ IdF- Pramenka $\mathrm{x}$ Württemberg $\mathrm{x}$ Ile de France (three breed crosses)

\footnotetext{
${ }^{1}$ Original scientific paper - supported by the Ministry of Science and Technology, Project no. TR6858 - Originalni naučni rad je finansiran od strane Ministarstva za nauku i tehnologiju Projektom broj: TR6858

${ }^{2}$ Mr Dragana Ružić-Muslić, research assistant, Dr Milan P.Petrović, scientific counselor, Mr Slavko Josipović, research assistant, Institute for Animal Husbandry, Belgrade-Zemun
} 
Average body mass of lambs at the beginning of trial was approx. $15 \mathrm{~kg}$ and at the end of trial approx. $30 \mathrm{~kg}$. Nutrition of lambs consisted of mother's milk, concentrate mixture and alfalfa hay (ad libitum).

Table 1. Structure and nutritious value of the concentrate mixture, $\%$

\begin{tabular}{|c|c|}
\hline H r a n i v a & \\
\hline Corn, grain & 60,00 \\
\hline Sunflower meal & 25,00 \\
\hline Meal & 12,00 \\
\hline Limestone & 0,60 \\
\hline Dicalcium phosphate & 0,80 \\
\hline Salt & 0,60 \\
\hline Pre mixture & 1,00 \\
\hline TOTAL & 100,00 \\
\hline Dry matter & 86,32 \\
\hline Crude protein & 15,86 \\
\hline NEM MJ & 7,07 \\
\hline
\end{tabular}

During trial all lambs had same housing and nutrition conditions. Control measuring was carried out in 15 day intervals using standard zoological methodology. At the end of trial 6 male and 6 female lambs were sacrificed in order to investigate yield and quality of meat.

Obtained results on monitored parameters were processed using variation-statistical methods.

Results and discussion

Data on production parameters of lambs according to genotype is presented in table 2 .

Table 2. Production results of lambs in fattening

Tabela 2. Proizvodni rezultati jagnjadi u tovu

\begin{tabular}{|l|l|l|}
\hline \multirow{2}{*}{ Parameters } & \multicolumn{2}{|c|}{ G e n o t y p e } \\
\cline { 2 - 3 } & I & II \\
\hline Body mass at the beginning of trial, kg & 15,15 & 15,12 \\
\hline Body mass at the end of trial, kg & 29,50 & 32,20 \\
\hline Total gain, kg & 14,35 & 17,08 \\
\hline Average daily gain, $\mathrm{g}$ & 239 & 285 \\
\hline
\end{tabular}

Genotype I- two breed crosses

Genotype II- three breed crosses

Data presented in table 2 show that mass of lambs of both investigated genotypes at the beginning of trial was almost identical: I $(15,15 \mathrm{~kg})$ and II $(15,12 \mathrm{~kg})$. However, values determined for this parameter at the age of 90 days (at the end of fattening) varied depending on the genotype: I $(29,50)$ and II $(32,20 \mathrm{~kg})$. Three breed crosses have realized higher body mass by $2,7 \mathrm{~kg}$ or $8,38 \%$ compared to two breed crosses. In regard to total gain, genotype II was superior by $15,98 \%$ in relation to genotype I. Average daily gain in three breed crosses was $285 \mathrm{~g}$ and in two breed crossed lambs $239 \mathrm{~g}$. Established differences in body mass of lambs at the age of 90 days, total gain and daily gain were statistically significant $(\mathrm{P}<0,05)$. Obtained values for average daily gain exceed results obtained in research by Petrović (1992) for stated trait in lambs of Württemberg breed in our breeding conditions. Namely, according to mentioned author, male lambs in fattening until the age of 90 days have realized average daily gain of 225 and female lambs of $208 \mathrm{~g}$. Also, in case of three breed crosses where terminal sire breed was Ile de France, obtained values for daily gain differ from values obtained in research by Mekić (1994) where suckling lambs of pure Ile de France breed during fattening until the age of 85 days realized average daily gain of $239 \mathrm{~g}$, which is at the level of our results determined for two breed crosses. This confirms the fact that in crossing, beside the genetic difference between populations that are 
being crossed, important factor for the success of crossing is also system of crossing. It is evident that beside the significant effect of heterosis in two breed crossing, three breed crossing of Pramenka breed and Württemberg with Il de France breed resulted in high yield and body mass caused by complete use of the effect of heterosis of individual animal as well as of mother (Petrović, 2000). Researches by other authors (Petrović et al. 1998, Cameron and Drury, 1985) confirm our statement.

Table 3. Consumption and conversion of feed and nutritious matters

\begin{tabular}{|l|l|l|}
\hline \multirow{2}{*}{\multicolumn{1}{|c|}{ Parameters }} & \multicolumn{2}{c|}{ G e n o t y p e } \\
\cline { 2 - 3 } & \multicolumn{2}{|c|}{ I I } \\
\hline Consumption, g/g/d & & \\
\hline Hay & 0,384 & 0,343 \\
Concentrate mixture & 0,500 & 0,505 \\
Milk & 0,204 & 0,203 \\
MJ NEM & 5,44 & 5,32 \\
SSP/DCP & 120,98 & 117,44 \\
\hline Conversion, g/kg & & \\
\hline Hay & 1610 & 1200 \\
Concentrate mixture & 2090 & 1770 \\
Milk & 850 & 710 \\
MJ NEM & 22,76 & 18,67 \\
SSP/DCP & 506 & 412 \\
\hline
\end{tabular}

Data presented in table 3 shows that in regard to consumption of food in three breed crosses, except for concentrate mixture, decreasing trend is present in comparison to two breed crosses. Consumption of hay by lambs of genotype II was lower by $10,68 \%$ compared to genotype I. At the same time, intake of energy expressed as MJ NEM was also lower in three breed crossed lambs by 2,20\% and DCP by approx. 2,93\% compared to crosses obtained in system of two bred crossing. By studying the effect of different crossing combinations: Pirot Pramenka x Merino Landschaf and Pirot Pramenka x Merino Landschaf x Ile de France, Petrović et al. (1995) determined that average daily consumption of energy (MJ NEM) and digestible crude proteins in stated order of treatments: 5,45 and $133 \mathrm{~g}$, and 5,11 and $128 \mathrm{~g}$. In regard to consumption of concentrate mixture our results differ from those obtained by Lanze et al. (1984) who have determined that crosses of Pinzirite breed with Ile de France breed consumed daily approx. $888 \mathrm{~g}$.

Analyzing the feed consumption per kg of gain (table 3) we can conclude that genotype II realized better feed, energy and DCP conversion compared to genotype I. Namely, three breed crosses have consumed less hay by $25,46 \%$ (410 g), concentrate by $15,31 \%$ (320g), milk by $16,47 \%$ (140g), MJ NEM 17,97\% $(4,09)$ and DCP by $18,58 \%(94 \mathrm{~g})$ compared to two breed crosses. Our results are in accordance with results obtained by Petrović et al. (1995) who stated that three breed crosses (Pramenka x Württemberg x Ile de France) consumed by $17,40 \%$ less concentrate for $\mathrm{kg}$ of gain compared to two breed crosses (Pramenka $\mathrm{x}$ Württemberg). Also, based on our research results we can confirm the conclusion of Fahmy (1989) about presence of negative correlation between average daily gain and feed conversion.

Analyzing the heterosis effect as biological phenomenon from biochemical aspect Sarsenov, 1982, Selkin et al., 1995, Sanninkov and Kazanovskij, 1981, quoted in Petrović et al., 1996 established relation between results of crossing of sheep with increased mitochondrial activity, higher stability of metabolic processes and activity of tissue ferments. Studies of correlation between the level of ferment activity and average daily gain in lambs show that the greatest correlation coefficients were determined at the age of lambs of 2 months. Authors pointed out that greater stability of metabolic processes typical for crosses is probably basis of their increased adaptability to various conditions of environment.

Considering that objective of lamb fattening is to obtain high quality meat in large quantities, in table 4 a comparative review of yield and major chemical-technological traits of meat of investigated genotypes is presented. 
Table 4. Yield and major chemical-technological traits of meat, $\%$

\begin{tabular}{|l|c|c|c|c|}
\hline \multirow{2}{*}{\multicolumn{2}{|c|}{ T r a i t s }} & \multicolumn{4}{c|}{ G e n o t y p e } \\
\cline { 2 - 5 } & \multicolumn{2}{c|}{ I } & \multicolumn{2}{c|}{ II } \\
\cline { 2 - 5 } & $\mathrm{X}$ & $\mathrm{Sd}$ & $\mathrm{X}$ & $\mathrm{Sd}$ \\
\hline Dressing percentage of carcass & 58,48 & 4,53 & 58,63 & 3,20 \\
\hline Meat of I category & 40,01 & 1,36 & 40,35 & 1,60 \\
\hline Meat of II category & 35,48 & 0,75 & 36,13 & 1,08 \\
\hline Meat of III category & 24,37 & 1,75 & 23,25 & 1,55 \\
\hline Chemical composition of meat (\%): & & & & \\
\hline Content of water & 73,59 & 1,16 & 73,29 & 1,27 \\
\hline Content of fat & 3,02 & 1,22 & 3,57 & 1,31 \\
\hline Content of protein & 22,19 & 1,05 & 22,05 & 0,46 \\
\hline Content of min. matters & 1,05 & 0,04 & 1,06 & 0,06 \\
\hline Loss by cooking & 25,86 & 1,33 & 25,73 & 1,03 \\
\hline Loss by roasting & 35,22 & 2,08 & 34,63 & 3,37 \\
\hline
\end{tabular}

Carcass dressing percentage as most important quantitative indicator of meat production was somewhat higher in genotype II $(58,63 \%)$ compared to genotype I $(58,48 \%)$ but without statistical confirmation $(\mathrm{P}>0,05)$. Obtained values are different from results obtained by Mekić (1994) who determined in lambs of Ile de France genotype which were slaughtered at age of 90 days average dressing percentage value of 56,02\% and Petrović (1992) who determined that lambs of Württemberg breed, depending on the sex, achieved dressing percentage of $57,67-58,21 \%$ which are lower values than our results for investigated trait.

Also, in regard to yield of meat according to different categories, observed differences in favour of three breed crosses were within random deviation limits $(\mathrm{P}>0,05)$. It is evident that lambs of genotype II had higher share of more desired meat categories (I and II) and less meat of category III. Data obtained in our research are in accordance with results obtained by Žujović et al. (1989) in investigation of crosses Pramenka x Württemberg where share of meat of category I of 40,19\%, meat of category II of $35,21 \%$ and meat of category III of $23,39 \%$ was determined.

Chemical analysis showed that genotype had no effect on content of water, fat, protein and mineral matters in samples of MLD. Considerable difference was established in content of fat between MLD samples of stated genotypes of $15,41 \%$.

Loss of mass by cooking and roasting of meat of lambs of investigated genotypes wasn't influenced by genotype since established values for stated traits were: $25,86 \%$ and $35,22 \%$ (I) and $25,73 \%$ and $34,63 \%$ (II).

Table 5. Sensor traits of roasted lamb meat, points

\begin{tabular}{|l|c|c|c|c|}
\hline \multirow{2}{*}{ Traits } & \multicolumn{4}{c|}{ G e n o t y e } \\
\cline { 2 - 5 } & \multicolumn{2}{|c|}{ I } & \multicolumn{2}{c|}{ II } \\
\cline { 2 - 5 } & $\mathrm{X}$ & $\mathrm{Sd}$ & $\mathrm{X}$ & $\mathrm{Sd}$ \\
\hline Tenderness & 3,67 & 0,54 & 3,77 & 0,61 \\
\hline Succulence & 3,60 & 0,55 & 3,65 & 0,74 \\
\hline Taste & 3,63 & 0,68 & 3,67 & 0,77 \\
\hline Aroma & 3,90 & 0,51 & 3,74 & 0,65 \\
\hline
\end{tabular}

According to sensor evaluation of lamb meat (table 5) somewhat better marks for these traits were established for meat from three breed crosses, however determined differences weren't statistically significant $(\mathrm{P}>0,05)$. Higher share of fat in MLD of this genotype (by approx.15,41\%) compared to genotype I caused better organoleptic traits. 


\section{Conclusion}

Based on obtained results of investigation of production parameters of fattening lambs depending on genotype the following can be concluded:

51. Lambs obtained using three breed crossing system have realized higher body mass at the end of trial $(32,20 \mathrm{~kg})$ compared to two breed crosses $(29,50 \mathrm{~kg})$ and at the same time realized higher total and average daily gain by approx. $16 \%(\mathrm{P}<0,05)$.

52. Lambs of genotype II consumed less hay by $10,68 \%$, MJ NEM by $2,20 \%$ and DCP by $2,93 \%$ compared to lambs of genotype I.

53. In regard to conversion of feed and nutritious matters three breed crosses consumed by $25,46 \%$ less hay, by $15,31 \%$ less concentrates, by $17,97 \%$ less energy (MJ NEM) and by $18,58 \%$ less digestible crude 54. protein for $\mathrm{kg}$ of gain compared to two breed crosses.

55. Analysis of dressing percentage, yield of meat according to categories, chemical-technological and sensor meat traits showed no statistically significant differences in investigated genotypes $(\mathrm{P}>0,05)$.

56. Carried out research established superiority of three breed crosses since thay realized higher gain with lower consumption of food, nutritious matters and energy and meat originating from lambs of genotype II had better sensor meat traits.

\section{PROIZVODNI PARAMETRI JAGNJADI U TOVU U ZAVISNOSTI OD GENOTIPA}

Dragana Ružić-Muslić, M. P.Petrović, S Josipović

$$
\text { Rezime }
$$

Ogledom je bilo obuhvaćeno 60 jagnjadi sisančadi predstavnika dva genotipa pri čemu je svaki bio zastupljen sa po 30 jedinki oba pola. Ispitivani materijal je pripadao sledećim genotipovima:

- $\mathrm{R}_{2}(\mathrm{PxW})$ - pramenka x virtemberg (dvorasni melezi)

- $\mathrm{F}_{1}\left(\mathrm{R}_{2}(\mathrm{PxW}) \mathrm{x}\right.$ IdF- pramenka x virtembergx Ile de France

Prosečna telesna masa grla na početku ogleda je bila oko $15 \mathrm{~kg}$, a na kraju oko $30 \mathrm{~kg}$. Ishrana jagnjadi se sastojala od majčinog mleka, smeše koncentrata i lucerkinog senom (po volji).

Od proizvodnih parametara pratili smo: telesnu masu, prosečan dnevni prirast, ukupan prirast, konzumiranje i konverziju hrane i hranljivih materija, randman, prinos mesa po kategorijama, hemijskotehnološka i senzorna svojstva mesa u zavisnosti od ispitivanih genotipova.

Statistička obrada dobijenih podataka je urađena primenom analize varijanse.

Završne telesne mase jagnjadi (sa 90 dana uzrasta) su iznosile: $29.50 \mathrm{~kg}$ (I) i $32.20 \mathrm{~kg}$ (II) Prosečan dnevni prirast za čitav period tova, po genotipovima I : II je iznosio $239 \mathrm{~g}: 285 \mathrm{~g}$.

Konzumiranje energije i SSP kod dvorasnih meleza je iznosilo: 5,44 MJ NEM i 120,98 g a kod trorasnih 5,32 MJ NEM i 117,44 g.

Utrošak sena i smeše koncentrata za kg prirasta kod genotipa I je iznosio: $1610 \mathrm{~g} \mathrm{i}$ 2090 g a kod genotipa II 1200 g i 1770 g. Konverzija energije i SSP se kretala od 18,67 MJ NEM i 412 g (genotip II ) do 22,76 MJ NEM i 506 g (genotip I).

$\mathrm{U}$ pogledu randmana trupa, prinosa mesa po kategorijama, hemijsko-tehnoloških i senzornih svojstava, nije utvrđen uticaj genotipa. Međutim, trorasni melezi su ostvarili neznatno više mesa I i II kategorije u poređenju sa dvorasnim. Pored toga i sadržaj masti u uzorku MLD je bio veći za 15,41\% što je doprinelo boljoj senzornoj oceni pečenog jagnjećeg mesa.

Izvedena istraživanja su pokazala da su trorasni melezi bili superiorniji, budući da su ostvarili veći prirast uz manji utrošak hrane, hranljivih materija i energije i povoljnija senzorna svojstva mesa. 


\section{Literatura}

1. CAMERON, N.D., DRURY, D.J. (1985): Comarison of terminal sire breeds for growth and carcass traits in crossbreed lambs. Anim.Produc. 40, 315-322.

2. FAHMY, M.H. (1989): The accumulative effect of Finnsheep breeding in crossbreeding schemes on market lamb production from crossbreed ewes. Canadian Journal of animal Science, 69 (1), 47-55

3. LANZA, A., ALEO, C. LICITRA, G. D'AMIGO, S. SHIES, L.(1984): Incrocio di prima generazione in allevamenti di pecore Pinzirite con impiego di arieti Ile de France, Texel, Merinolandschaf e Barbareshi, Estratto da Tecnica Agricola n. 4 - Anno XXXVI.

4. MEKIĆ,C. (1994): Ispitivanje reproduktivnih i proizvodnih osobina Il de france rase ovaca. Doktorska disertacija, Univerzitet u Beogradu

5. NEGOVANOVIĆ, D., PAVLIČEVIĆ, A., JUZBAŠIĆ, N. (1983): Uticaj nivoa i medjusobnog odnosa energije i proteina na svarljivost obroka i proizvodne rezultate u tovu jagnjadi. Zbornik radova Poljoprivrednog fakulteta, godina 27 - 30, sv. 587, 53-62, Beograd.

6. PETROVIĆ, P.M. (1992): Ispitivanje reproduktivnih i proizvodnih osobina virtemberške rase ovaca. Doktorska disertacija, Univerzitet u Beogradu

7. PETROVIĆ, P.M., NEGOVANOVIĆ, D., ŽUJOVIĆ, M. (1995): Nove mogućnosti povećanja proizvodnje jagnjećeg mesa primenom metode ukrštanja. Međunarodni simpozijum. Biotehnologija u stočarstvu, 11 (3-6), 97-103

8. PETROVIĆ, P.M., VLAHOVIĆ MILICA, ŽUJOVIĆ, M., NEGOVANOVIĆ, D., MEKIĆ, C., RUŽIĆ DRAGANA (1996): Neki aspekti biohemijske osnove heterozisa kod ovaca. Biotehnologija u stočarstvu, 12 (3-4), 67-72

9. PETROVIĆ, P.M., ŽUJOVIĆ, M., NEGOVANOVIĆ, D., SKALICKI, Z., RUŽIĆ DRAGANA, STRSOGLAVEC STELA (1998): Uticaj sistema ukrštanja na varijabilnost tovnih osobina jagnjadi. Savremena poljoprivreda, 48, 1-2, 97-100

10. PETROVIĆ, P.M. (2000): Genetika i oplemenjivanje ovaca. Naučna, Beograd

11. SOEPARNO, I., DAVIES, H.L. (1987): Studies on the growth carcass composition in daldale wether lambs. The effect of dietary protein/energy ratio. Austral. Jour. Agr. Res. 38,2,417-426

12. ZEREMSKI, D., PAVLIČEVIĆ, A., GRUBIĆ, G.(1989): Uticaj sastava obroka na efikasnost tova jagnjadi i šilježadi. XIII Savetovanje Jugoslovenskog odbora za ovčarstvo i kozarstvo, 115-127, Palić.

13. ŽUJOVIĆ, M., NENADIĆ, M., STOJKOVIĆ, M., JOSIPOVIĆ, S. (1989): Prilog poznavanju prinosa kvaliteta mesa jaganjaca pirotske pramenke i meleza sa virtembergom. Kvalitet mesa i standardizacija. Jugoinspekt, Donji Milanovac 